\title{
Private Political Violence and Boss-Rule in the Philippines
}

\author{
Peter Kreuzer
}

\begin{abstract}
Despite its rather strong and venerable democratic credentials the Philippines is still marred by political violence. Targeted killings and physical harassment by vigilantes, death squads, private armed groups, para-military militias, the police or members of the armed forces as well as violent competition for political jobs cost hundreds of lives every year. One central anchor point of this broad range of violent actors and forms are the locally embedded political bosses. (Defective) democracy provides an ideal frame for the continuing competition between various segments of the highly fragmented elite. However, political competition includes a huge number of dirty tricks including the use of violence. The paper shows how the bosses succeeded in controlling most means of political violence employed and were thereby able to advance their interests to an extraordinary extent. Upholding private control over means of violence furthered their interests as a political class even though it weakened the state.
\end{abstract}

Keywords: Philippines; political violence; bossism; vigilantism; death squad

\section{Philippine Politics - Violent Bossist Democracy}

We all employ goons. [...] The goons here are killers. The more they have killed, the better they are as bodyguards.

(Anonymous Politician in Interview early 1960s) ${ }^{1}$

Four years after the USA took over colonial power from Spain in 1898 the US Congress passed the Philippine Organic Act that established a bicameral Philippine Assembly, the lower house of which was to be staffed by elected Filipinos. The first lower house elections were held in 1907. In 1916 the Philippine Autonomy Act reframed the Philippine Assembly. Hence it became a two-chamber legislature, whose members were to be elected. Finally in 1935 the first Filipino President and Vice-President were elected on the basis of the Philippine Independence Act of 1934, which mandated a ten-year transition period leading to full sovereignty.

The Second World War and the Japanese occupation of the Philippines foiled American and Filipino plans for independence - the Philippines became part of the so called 
Greater East Asia Co-Prosperity Sphere for more than three years. After U.S. forces had freed the Philippines, decolonization was accomplished with U.S. recognition of Philippine independence on July 4, 1946. The first post-war elections of April 23, 1946 even pre-date Philippine independence. From then on, Philippine politics was punctuated by regular and nationwide elections for a huge number of local and national public offices.

It is true that President Marcos, the only president ever to be re-elected, ${ }^{2}$ declared Martial law in 1972 and thereby prolonged his (from then on authoritarian) rule by 15 years. After this authoritarian interplay of 15 years, democracy returned with the famous People Power revolution of 1986, which brought Corazon Aquino to power. Since then, each presidential election brought a new president - Aquino, Ramos, Estrada and currently Gloria Macapagal-Arroyo. ${ }^{3}$ Likewise the members of Senate, Congress and several thousand local electoral offices have been elected in and out of office in regular intervals.

Even though the Philippines exhibit such an extraordinarily long history of electoral democracy, the state never enjoyed a monopoly on the means of violence. Alongside legal state agents of coercion there were always private and hybrid organizations that employed violence for a variety of political and economic aims. At no point did either democracy or state-building succeed in lessening or eradicating the private armed groups (PAGs) beholden to political heavyweights, paramilitary cultist or criminal vigilantes, militias, death squads and policemen or Armed Forces personnel, who overstepped the limits of legality with impunity.

In other countries the overthrow of dictatorships brought with it some effort to come to terms with the past, be it through truth commissions or other means. Nothing like this ever happened in the Philippines during the two decades after the overthrow of Ferdinand Marcos, the lone dictator in an otherwise democratic past, in 1986. Total impunity not only characterized the Marcos years, but likewise the political violence that shook the Philippines during the decades of democratic rule from the inauguration of President Corazon Aquino in 1986 to the present.

The complete lack of coming to terms with the past and the present impunity came about because the People Power revolution of 1986 was not a revolution but a restoration of pre martial law rule of democratically masked bosses, constantly adapting to changing environments. In order to uphold their rule the returned old bosses, as well as their descendants and a number of new strongmen, continued to rule by democratically legitimated boss rule. They continued utilizing those very same instruments of private and semiprivate violence which had characterized Philippine politics of foregoing decades. Private violence employed for political aims never was an aberration from otherwise democratic governance, but a necessary ingredient of electoral democracy sustained and developed further in the Philippines over the previous century.

The following paper will give an overview over the various types of violence employed in the political sphere. It will show how these forms and agents are held together by the notion of private, personalized control by local bosses, and how even state instruments of coercion are included in the repertoire of privately controlled violence as are seemingly bottom-up vigilante organizations. The conclusion will bring the various his-

2 He was elected for the first time in 1965, but gained re-election in 1969.

3 Admittedly Macapagal-Arroyo is a special case, as she took over from Estrada in the crisis of 2001. However, she won the elections of 2004. 
torical and analytical strands together and show how patronage and private political violence go together.

\section{Types of Political Violence in the Philippines}

States, societies or regimes in transition are highly volatile and susceptible to intrasocietal violence of various kinds. However, it is generally assumed that long-standing and consolidated democracies make for peaceful societies. It might then be argued that a country with such a venerable democratic tradition such as the Philippines would exemplify peaceful management and resolution of political and social conflicts of all kinds.

However, this has clearly never been the case. With respect to political violence, which is the focus of this paper, it can be stated that violence has always been, and still is, an important means for winning or upholding power and relegating contending forces to the background. Physical violence is, as I will argue, a defining feature of this peculiar brand of governance.

What then are the major types of politically-related violence in the Philippines?

First, the Philippines harbour one of the most durable ethno-religious civil wars worldwide - against Muslim Secessionists on the Southern Island of Mindanao and the Sulu Archipelago. It has also not succeeded in pacifying the Communist insurgents. Both civil wars began in the late 1960s and early 1970s and continue to the very present.

Second, since the return to democratic rule in 1986, there have been more than 10 coup-attempts against the elected government, all of which were engineered by members of elite units of the Armed Forces of the Philippines (AFP). The coup-leaders were hardly ever punished - many took part in several coups, others became prominent politicians.

Third, there is a large number of extrajudicial executions, mostly aiming at representatives of left-leaning activists. Other victims of such killings are journalists, who are critical of various local grievances and probably dig too deeply into the machinations of powerful local bosses. Mention should also be made of the growing number of judges killed by assassins. In a number of cities criminal suspects have been killed by unknown assailants in 'death squad style'. In the more rural areas landlords and other businessmen quite regularly employ hoodlums to enforce their dominant position. Hundreds, if not thousands of would-be beneficiaries of the land reform programme have been killed since the respective law was passed in 1988.

Fourth, we should take notice of the centrepiece of democratic governance itself - the elections - which cost between 100 and 200 lives per election. Of these, between 10 and 30 percent are candidates or office holders, the rest politicians' henchmen and followers or innocent bystanders. This type of inter-elite violence recedes in years without elections, but never completely disappears.

Although these various types of violence have been best documented in recent decades, none of them can be reduced simply to these documented forms, with the exception of the politicized armed forces engaging in coups. Rural rebellion and its suppression can be traced back to Spanish colonial times, election violence already played a role in the early elections under American tutelage and the killing of activists likewise can be traced back to the early years of the Communist movement in the 1930s.

As this paper focuses on the political bosses as entrepreneurs in violence, the following discussion of forms and agents of violence will only focus on those phenomena most directly connected to them. 


\section{Private Armed Groups (PAGs) as ingredient of democratically framed boss-rule}

Philippine socio-political order has variously been described as feudal or oligarchic, as boss rule, bossism, caciquism, cacique democracy, mafia democracy, familialism, or an anarchy of families. Despite variations in emphasis all characterizations share one point: a coercion based patron-client system that successfully upholds the rule of the few.

The modern Filipino political and economic elite developed out of two mestizo groups, which slowly gained control over vast tracts of land during the $18^{\text {th }}$ and $19^{\text {th }}$ century: a large number of Chinese-Filipino and a much smaller number of Spanish-Filipino mestizos. Towards the end of Spanish rule in the late $19^{\text {th }}$ century there have been around 35,000 Spanish and 200,000 Chinese mestizos in the Philippines (Simbulan 2005, 23). Together with the religious orders these groups emerged as hacendados (big landowners), when the encomienda system slowly gave way to other forms of land ownership. The development of vast haciendas started in earnest, when the trade monopoly of the Spanish Royal Company lapsed in 1835 and the port of Manila was opened to foreign trade two years later.

Together with a rather small non-mestizo indigenous elite, that had transformed traditional authority into the modern state-delegated authority of alcade mayor (province governors), gobernadorcillo (town mayors), and a number of subordinate positions, the mestizos developed into a ruling oligarchy, the principalia. This group slowly developed an extraordinary homogeneity with respect to world-view and culture. Its members were thoroughly hispanised and had a "virtual monopoly on public office and higher education" (Simbulan 2005, 28). They regularly inter-married and controlled most of the agricultural lands - the rest being under the control of various religious orders. They also engaged in the internationalized segments of Philippine economy (Anderson 1998, 198). At the same time local orientation continued, as the various regions of the Philippines "entered the world economic system at different times, under different terms of trade, and with different systems of production" (Alfred McCoy cited in Abinales/Amoroso 2005, 83, see also Franco 2001, 36 for a study on local governance see Bankoff 1992).

Although unintentional, American colonial power made the already powerful principalia into a class, which totally dominated the rest of society, monopolizing not only economic, but also political and social power. Firstly, the Americans strengthened the economic dominance of the principalia by expropriating a large part of the agricultural lands owned by the religious orders and selling it to wealthy hacendados. Secondly, the USA included the Philippines into the American market which provided an extraordinary boost for the production of cash crops. Thirdly, the Americans made the Philippines into their model for the establishment of democratic governance in non-Western societies. The way this was accomplished (from the local to the national level) allowed the hacendados and their henchmen to successively capture level after level of the newly built-up electoral democracy. The early development of a political system and a lag in the development of a bureaucracy subsequently resulted in "the subordination of a weakly insulated bureaucracy (including the police) to elected local and national politicians" (Hedman/Sidel 2000, 39).

Coercion and violence were a distinct feature of the caciques' political entrenchment in municipalities, districts and provinces and continued to play a significant role thereafter. One of the traditions of this semi-feudal arrangement was "the keeping of one's own band of armed retainers" (Kroef 1990, 21). The early establishment of democratic governance enabled local elites not only to retain their private goons, but also to privatize the 
municipal police forces. By and large, as American colonial officials noted, municipal police forces acted as "the political henchmen, and in too many instances the personal muchachos of the presidentes and local bosses. Underpaid, only partially trained, and poorly equipped $[\ldots]$ they often served the reigning local cacique rather than the public. In numerous instances they were instances of oppression rather than agents of the law" (Ralston Hayden 1947 cited in Simbulan 2005, 220-221; see also: Sidel 1999, 17; Go 2008, 245).

Out of these historical developments emerged a specific ruling class, made up of families and strongmen, combining political, economic and social power and, if necessary, making use of private or privatized state-violence to defend their position.

Sidel defines this type of rule as bossism, which in his view is a "particular manifestation of a more generalized social formation found when the trappings of formal electoral democracy are superimposed upon a state apparatus at an early stage of capital accumulation. Bossism [...] reflects [...] the decisive subordination of the state apparatus to elected officials against the backdrop of what might loosely be termed "primitive accumulation"" (Sidel 1999, 146). Bosses then are "predatory power brokers who achieve monopolistic control over both coercive and economic resources within given territorial jurisdictions or bailiwicks" (Sidel 1999, 19). The state becomes "a complex set of predatory mechanisms for the private exploitation and accumulation of the [...] human, natural and monetary resources" (Sidel 1999, 146; see also Hutchroft 1991).

PAGs still are a crucial feature of elite-rule in many parts of the Philippines. Data on number and size during the American colonial times do not exist, however, for latter years, there are at least a number of estimations. In 1970, according to a semi-official counting the Philippines harboured at least 80 private armies beholden to political warlords. Of these six were said to be members of the Senate, 37 members of the Lower House, the others were either governor, city mayor or occupied other positions of political or economic prominence (Tutay 1970a, 1). The actual number of PAGs probably was much higher, as developments in late 1970 indicate when a huge number of (de facto) private armies were legalized by registering them as security agencies. Within 44 days 315 new private security agencies were registered. The total number thereby more than doubled from 192 to 507. Many of the newly registered ones were owned by relatives of political warlords (Tutay 1971b, Rufin 1971). In 1993 it was said that there existed about 560 PAGs. However, this number does not include the officially licensed private security personnel numbering about 182,000 (Tiglao 1993, 26). In 2004 according to the PNP, there were over 90 known "private armies" employed by politicians across the Philippines in the [...] national elections" (Mediavilla 2007). In 2007 there existed according to the police 56 PAGs in the ARMM, 30 PAGs on Luzon and five in the Visayas (Mediavilla 2007). In both cases officially licensed private security agencies are not included. ${ }^{4}$ Whether the lower numbers in the new Millennium really reflect a decrease or a politically motivated statistical "downsizing" remains an open question. That private armies are still a mainstream phenomenon of Philippine politics is illustrated by a Senate Bill introduced by Senator Antonio Trillanes in 2008. This bill aims at "defining 'private armies

4 The Philippine Association of Detective and Protective Agency Operators, Inc (PADPAO) has about 1800 members "with an estimated personnel strength of 230,000 security personnel" (SAGSD 2008). 
and other armed groups' implementing the constitutional provision for their dismantling, prescribing penalties therefore, and for other purposes" (Senate Bill No. 2620, 2008).

\section{Bossism and the role of the police, armed forces and para- military militias}

The widespread existence and use of Private Armed Groups in the service of individual bosses or political families raises the question of their relationship to the institutional agents of state violence, i.e. the police and the armed forces. Are the latter simply too weak to hinder private actors' efforts at asserting themselves by violent means, or are they themselves part of a wider system of privatized violence?

With respect to the police, the answer is rather clear: in many cases, the police functions as an armed representative of the private interest of local powerholders. Policemen are used as private enforcers of strongmen and local elite's interests on a regular basis. Probably the main reason for this state of affairs is the direct subordination of the local police under the control of the local political elite, which has been re-established in the wake of the ouster of President Marcos, who had integrated the local police into a national hierarchy and made it part of the AFP. This was reversed after the return to democratic rule. The new Police law, Republic Act 6975 of 1990, not only demilitarized the police, but also reinstated local officials in their control functions. Section 51 of R.A. 6975 gives wide-ranging powers over the selection and guidance of the local police to local political officials. City and municipal mayors "exercise operational supervision and control over PNP units" (R.A. 6975 Sect. 51). For all practical purposes R.A. 6975 and later laws on the PNP (R.A. 8551) put the local PNP under the mayors' control. Under conditions of local boss-rule the police can easily become an armed group used for furthering private interests. The negative effects become visible only in rather dramatic circumstances as for example in Abra in 2007, when the Local Chief Executive's deputation in the operational control and supervision of PNP personnel was suspended and all police personnel were reassigned to other positions in the wake of a dramatic escalation of political violence. In Abra, a small province of 200,000 inhabitants, more than 30 politicians had been killed in a political vendetta between the dominant clan of the Valeras and a number of challengers, when the national level finally intervened with special task forces and superior fire power (for details see: Police Regional Office Cordillera 2007, 2, Pumecha 2007, Kreuzer 2007).

With respect to the AFP the situation is less clear, as there exists no formal control relationship between the AFP and local government officials. Therefore local army detachments are a strong and independent force which is formally beyond the reach of politicians. Nevertheless the history of the AFP is one of instrumentalization and partial politization by a ruling elite. This came about by an uninterrupted tradition of counterinsurgency dating back to the late 1940s, when the Hukbalahap (Huk), a former anti-Japanese guerrilla force, built-up and supported by the Communist Party of the Philippines, went underground and took a violent path towards revolution.

A number of AFP officers in later years held the ruling elite responsible for the dramatic levels of inequality and poverty which sparked the rebellion. Despite their criticism, the officers without exception embraced the idea of counterinsurgency by forcefully arguing for a strong policy aimed at the restoration of law and order. The officers' attempts at depoliticizing their own tasks by framing them in the language of law and order eventually made them into accomplices of the political establishment. By focussing on law and 
order the officers effectively described the insurgencies in the language of lawlessness and crime. The military's readiness to fight the insurgents in the name of law and order and a depoliticised national interest made the AFP into willing instruments of the elite that tried to evade any concessions.

Counterinsurgency-warfare, which relied heavily on semi-private militias, fragmented the Armed Forces as an institution. Because of chronic lack of funding local detachments quite often lived from the land and the people they were supposed to protect. Not infrequently, they were quietly financed by local strongmen in return for providing some 'extra service'. They lacked local familiarity and therefore had to cooperate and utilize local militias, which were formally under their control. In reality, however, these often answered to local strongmen. Thereby the AFP from the early years of counterinsurgency became partially dependent on militias and local politicians and colluded in their shady dealings.

For a variety of reasons the Philippine state conceived of counterinsurgency in (para-) military terms only. The strategy which focuses on militias to a large degree goes back to the late 1940s, when a number of local forces were created in order to annihilate Hukinsurgents. ${ }^{5}$ The problem, which was to continue to the present, became visible in the early years of the program: The militias "took orders from the military but they were employees of local elites who were disliked by the people because of a bad reputation" (Espino 2004, 7). The forays of these types of forces mostly followed a devastating pattern. Lawrence Greenberg, a US-army officer, describes that "Government forces stayed close to their barracks and bands of 'Civil Guards' (private armies hired by landlords), tried to protect plantations and went on occasional, and always unproductive, 'Huk hunts." Later the Police Constabulary adopted the same 'strategy': "Company after company of constabulary troops charged into Huklandia burning entire villages, slaughtering farm animals, and killing or imprisoning many innocent peasants in their search for the elusive insurgents" (Greenberg 1987, 69). When the armed forces became more prominent in the fight against the Huks, they showed themselves to be a similarly oppressive force (Greenberg 1987, 75-76). Even though during the last years of the Huk Rebellion AFP troops and militias behaved more disciplined the fundamental problem of repressive violence against the population at large and the use of violence for private elite interests remained unabated.

Like the early militias employed in the anti-Huk campaign, all later successor organizations used in later counterinsurgency operations against the Communist or Muslim insurgents shared one decisive defining element: the partial or at times even total control of local landlord-businessmen-politicians. Time and again similar consequences arose. When the Barrio Self-Defense Units (BSDU) were organized under President Marcos in the late 1960s, they were officially under AFP control. Nevertheless these militias were largely independent in their operations and the small number of AFP-personnel, tasked with their control "in the long run, became their buddies and partners" (Espino 2004, 9). As funding was insufficient, many BSDU units relied on local support of barrio officials and a number of them "became bodyguards of influential people and politicians because

5 Huk is a shortcut for Hukbalahap, an early semi-revolutionary organization, which championed agrarian reform and staged a violent rebellion in 1946, after they had been denied legitimate political participation in the parliamentary arena (Kerkvliet 1977, Greenberg 1987). 
of remunerations and benefits they received from them. Militia members were performing everything for the politicians instead of doing their duty as a village defense unit" (Espino 2004, 9). When in 1976 the Integrated Civilian Home Defense Force (ICHDF) was developed the same problem surfaced from the very beginning: "the mission and tasks of the ICHDF were unclear and its utilization was placed in the hands of both military and police commanders who were influenced by the local executives and powerful politicians. This militia unit did not receive any training and was not given even enough stipend for their services" (Espino 2004, 11). Powerful individuals continued the old practice of financing CHDF units, which then were employed to secure their economic as well as political interests.

The return to democracy brought no new counter-insurgency strategy which would have successfully tackled the political and economic woes underlying the decades-old insurgency, but only restructured the militias. One of the most important initial aims of the new regime had been the dissolution of all paramilitary forces including the Civilian Home Defense Forces (1987 Constitution art. $18 \mathrm{sec}$. 24). As the insurgency continued, the government felt itself in a dilemma. They wanted to dismantle the discredited CHDF and at the same time deploy paramilitary forces in order to battle the Communist insurrection. In mid 1987 it was decided that a new organization, the Citizen Armed Forces Geographical Units (CAFGU), should replace the CHDF. The CAFGU were to subdivide in three categories (1) the inactives (qualified, but not activated), (2) the actives, which were volunteers, armed by the Army or the PC (Philippine Constabulary; P.K.), and used in order to complement military operations, (3) the special actives, "who are active personnel paid by a private employer" (Lawyers Committee 1990, 66).

After initial reluctance the military and police finally embraced the CAFGU program of the Aquino government. They realized that it provided them with an opportunity to recycle and re-legitimize the CHDF and a number of other private armed groups under their control by recruiting them as members of the new CAFGU. Towards the end of 1988 it was reported that 36,000 members of the CHDF were undergoing training, preparing them for CAFGU membership.

Not only for the military, but for various private interests, too, it made sense to use the legislation on the CAFGU in order to legalize and legitimize their PAGs. Many seem to have used the opportunity to make legitimate militias out of their armed retainers or give a new "birth" to their privately controlled CHDF-units. Even though "special active auxiliaries" - those financed by private interests - should play a supportive role only, they actually seemed to have formed the bulk of the CAFGUs in the formative years (Kroef 1990, 14).

A huge number of companies, especially those active in the fields of extractive industries and in the planting of cash crops, picked up the opportunity to establish their own CAFGU units (Lawyers Committee 1988, 34-35, Lawyers Committee 1990, 39-40, 105, Human Rights Watch 1996). As Leon and Escobido report in a detailed study of the Banana industry " $(\mathrm{m})$ ost of the large commercial plantations [...] financed the establishment and/or made use of paramilitary forces, particularly the Civilian Armed Forces Geographical Units (CAFGU) to act as security guards and provided financial support to Army infantry battalions stationed near the farms. Some banana companies also used the presence of CAFGUs as a threat of violence to control the result of trade union certification campaigns in their plantations and ensure that company unions are endorsed by workers" (Leon/Escobido 2004, 53, see also 72-73).

It seems fair to say, that the CAFGU program enabled a huge number of private armed groups to mask as government sponsored militias. These forces are still under some kind 
of combined command and supervision by local civilian and military officials. The reorganization of the civilian auxiliary forces, which should have marked the clear-cut break between authoritarianism and democracy actually symbolized in a most dramatic way continuities in the semi-privatization of the means of violence persisting independent of regime type.

\section{Bottom-up violence and the problem of elite control}

All types of private agents of political violence discussed so far had a direct connection to the political elite on the local level. They were either directly beholden to them or they could easily be instrumentalized in order to work for the politicians' interests.

But the modern Philippines also exhibit a tradition of private violence arising from the grass-roots in times of perceived crisis. One root out of which those agents of violence developed is millenarianism, which has been and still is a prominent feature in various regions of the country. A number of vigilante groups, which emerged since the 1970s had their origins in such millenarian cults. Others, while literally having nothing in common with millenarian sects and cults, made use of a number of their signifiers - amulets, beliefs in magical power, prophecies and the like - in order to strengthen their organizations.

Such bottom-up vigilante organizations were a marginal phenomena until the late 1970s and early 1980s, when they were put to use by the Marcos regime for the first time in the fight against Communist and Muslim insurgents. These years "witnessed the formation and organization of religious fanatics and tribal minorities into anti-communist movements in remote areas of Mindanao similar to the Laos, Cambodia and Vietnam experience" (Malajacan 1988, 6). These forces, even though initially under the control of individual Army or PC officers on the local level, easily transformed into autonomous units that terrorized the populations of many, mostly backward regions. Most dreaded were religious groups like the Tadtad (also known as Corazon Señor) initially active in the region around Davao (Mindanao), whose name, meaning chop-chop, imitates the sound of a bolo knife cutting into human flesh. Similar groups in other regions were Rock Christ, active in Misamis Occidental and Zamboanga del Sur (also Mindanao), the World Crusaders Army, the Philippine Divine Missionaries of Christ, the Tres Cantos or the 4Ks. Even though a number of these cults existed before, they became really dangerous and violent only after having been encouraged, trained and supplied with weapons by members of either the CHDF, the PC or the Army.

The various types of counter-insurgency related vigilante organizations ${ }^{6}$ provide a crucial backdrop of the dramatic developments of the early years of democratic governance in and after 1986. The other is the development of urban assassination squads by the Communist insurgents around 1984/85. These so-called "Sparrow" units aimed especially at killing representatives of the state, but eventually became quite indiscriminate in their violence. Interestingly, the anti-communist counter-violence remained modest in the large cities during the last years of Marcos, when life became ever more dangerous to local representatives of the state. The step towards an extended use of anti-Sparrow

6 For theoretical perspectives on vigilantism see for example: Abrahams 2008, Rosenbaum/Sederberg 1974, Sen/Pratten 2008. 
counter-terror and a massive strengthening of un-civil society became a phenomenon of the early years of the transition to democracy.

One of the most outstanding phenomena of these times was the huge number of vigilante organizations which cropped up within a few months time. The vigilantes initially developed as a local reaction to the increasingly indiscriminate violence of the Sparrow units and rising criminality in a number of cities. In the beginning the vigilantes were quite popular amongst the local population. In Manila, after more than a hundred policemen and soldiers had been killed by the NPA Sparrow units within less than one year, Alfredo Lim, chief of the Manila-police, announced, that he was to organize a vigilante force in order to combat the NPA in Manila. "Within a week, as many as 5,000 residents reportedly lined up at police headquarters to enlist; some brought firearms" (Lawyers Committee for Human Rights 1988, 14, Guyot 1988, 12). In Davao City, the local vigilante organization, the Alsa Masa, seems also to have been accepted by the majority of the people, as they protected them against the violence of the NPA-sparrows and tried to curb criminality.

Even though the Alsa Masa like its Manila Counterpart, the Manila Crusaders for Peace and Democracy (MCPD) had the outward appearance of a grassroots organization, their phenomenal rise to a membership of several thousand people was possible only because they were supported and in due course led by local strongmen. As the MCPD depended on the Manila police chief, so the Alsa Masa depended on the support of the local Commander of the Philippine Constabulary Lt. Col. Franco Calida. Building on a small street gang (Guyot 1988), he constructed the largest and most powerful vigilante organization the Philippines have seen yet. The group could not have become so powerful were it not for the active support of its self-proclaimed godfather Lt. Col. Calida. Within a few months the organization numbered thousands of members from all over the city. Alsa Masa manned checkpoints and patrolled the streets, with specific ID cards given to the local people (for a "fee") in order to better control all movements. Suspicious people were "arrested" and handed over to the police. The peace and order situation improved significantly. Therefore President Aquino in a 1986 visit to Davao praised Alsa Masa as a model in People Power and in the fight against communism. She said: "We look up to you as an example. [...] While other regions are experiencing problems in fighting the insurgency, you here [...] have set the example" (cited in Lawyers Committee 1988, 139).

Aquino, as all the other national and local politicians lauding the vigilantes, conveniently "forgot" their sordid side. Already at the time when Aquino held her speech in Davao, it was abundantly clear that Alsa Masa was responsible for harassments and beatings, for enforcing financial contributions, for torture and extrajudicial executions. ${ }^{7}$ Actually Alsa Masa countered the NPA-terror by establishing her own regime of even more menacing counter-terror. The threats were broadcast over radio, as for example by Jun Porra Pala a right wing radio commentator. Pala in 1987 warned his and Alsa Masas enemies without mincing his words: "We will exhibit your head in the plaza. Just one

7 Most of the victims were suspected NPA sparrows. In an interview Alsa Masa godfather said, that about 50 sparrows were killed by Alsa Masa (Guyot 1988, 9). However, besides these a number of innocent persons fell victim to the savagery of the Alsa Masa. 
order to our anti-Communist forces, your head will be cut off. Damn you, your brains will be scattered in the streets" (Jun Porra Pala cited in Lawyers Committee 1988, 26-27).

Amongst local politicians and businessmen Alsa Masa had powerful patrons contributing to the coffers of the organization. Alsa Masa was supported by the Presidential assistant Jesus "Chito" Ayala and by the city government which contributed at least 9,000 US\$ and helped Alsa Masa in devising livelihood projects for its members. Newly elected mayor Rodrigo Duterte who, with short interruptions, has held the mayoral position up to the present moment (2008) seems to have been an ardent supporter of Calida and the Alsa Masa In Duterte's perspective Alsa Masa insured the necessary stability for the economic recovery of Davao City and had "become the community spirit of Davao City" (Guyot 1988, 11).

Vigilantes sprang up in many other regions of the Philippines, ${ }^{8}$ a number on the model of the Alsa Masa, while others lacked Alsa Masa's relative visibility and operated more like extortion rackets and criminal gangs. Tadtad, as already mentioned, were an extraordinarily cruel cultist vigilante organization and greatly expanded its reach at this time. Tadtad chapters could be found in various regions of Mindanao, in Negros, Cebu, Leyte and a number of other islands. Even though they probably were independent from each other, they subscribed to similar cultist practices, such as hacking their victims to deaths with bolos, drinking human blood, and devouring parts of human livers. As stated above in various regions local political elites, industrial corporations or Army detachments established their own vigilante organizations which were used to further the interests of their sponsors but which, time and again, also took on a life on their own. The language employed by the vigilantes' spokesmen in various parts of the country was blatantly threatening. Mariano Ventura, leader of a vigilante movement in Cebu, told journalists:

"I have now issued orders to shoot on sight. We will shoot the NPA's, the social investigators, the political organizers and the Armed City Partisans. [...] We will shoot them and we will bury them. That would be the best method. There are no problems whatsoever. There will be no investigations. [...] There are no limits when it comes to war" (cited in Lawyers Committee 1988, 71).

A significant part of the vigilante violence seems to have been random, aimed at sowing fear and terror. Most of the violence, however, aimed at people believed to be sympathizers of the left, or activists of various organizations aiming at uplifting the poor and marginalized.

This main direction of vigilante violence explains why many state actors chose to temporarily support them, even though they could exercise only inadequate control. The vigilantes provided crucial services in the elite's effort for a restorative reframing of the vague ideology of empowerment underlying People Power. Anti-communist vigilantism was portrayed as a continuation of the People Power revolution. The vigilantes, in a rather grotesque way, symbolized the continuity of People Power at a time when the traditional elites were fighting to divert the emancipatory impetus of reform and reconstruct the old order where they had reigned supreme. In order to succeed, they had to redraw the collective cognitive map of the People Power revolution in such a way that their own

8 It is estimated, that by 1987 there were more than 200 vigilante groups all over the Philippines, a number which rose to about 640 until 1989 (Hedman 2000, 130). Membership of these groups is said to have been around 30,000 in late 1987 with an average local group size of 150 (Kowalewski 1992, 74). 
continued dominance would become invisible and the energies were deflected towards other aims. By empowering the vigilantes they succeeded in identifying "the key combatants as vigilantes defending the good people of the Philippines from communist threats to peace and democracy" (Hedman 2000, 126). They successfully substituted a temporal "democratization of violence" for the threatening perspective of "far-reaching structural reforms of Philippine state and society" (Hedman 2000, 126). The elite readily tolerated violent excesses because they realized "the power of severed heads and dismembered, rotting corpses not only to frighten and humiliate an adversarial community, but also to stir dread and awe" (Hedman 2000, 131). The atrocities committed by the vigilantes as well as the terror accompanying them had an extraordinarily pleasant side-effect from the elite's point of view: the vigilantes succeeded in terrorizing a whole people into obedience. Once this was accomplished most of the vigilante organizations melted back into the population. The Kuratong Baleleng continued as a crime syndicate, the Tadtad is said to have continued as a cult, however, the space open to them in the late 1980s has been largely closed in the early 1990s. Members of a number of vigilante organizations were integrated on an individual or small-group basis into those forces traditionally at the disposal of the powerful. Under conditions of stable cacique rule the costs of grassroots vigilantism are simply too high when compared with its benefits. Should a need for private violence arise in order to assert the caciques' aims, the much less visible more easily controlled private armies, paramilitaries, local police or AFP-units could be entrusted with the task. So whereas the open vigilante phenomenon of the late 1980s is a thing of the past, private violence is not. It merely changed its form so that it became less visible and complicity can therefore be more easily denied.

One new form such violence took in recent years is the death squad employed against suspected criminals which finds its Philippine model in Davao City. Here more than 500 people, all suspected of being criminals, have been killed by unknown assailants popularly called the Davao Death Squad (DDS) during the last few years. Not even one of the cases has been solved. The mayor of Davao, Rodrigo Duterte, who in the late 1980s subsidized the Alsa Masa from the communal budget, feigns innocence and powerlessness but at the same time states publicly:

"My hatred of criminals - that's what changed Davao. [...] But what actually, to me, made the difference is at least the criminals here are afraid of the law. Here, if you are a police officer and you steal from a civilian, putang ina (motherfuckers; P.K), I'm going to kill you. God, I will! I'll M16 you in public. [...] Why would you be afraid each time I say, 'You criminals are sons of bitches! I'm going to kill all of you!' If you're afraid, then you must be a criminal. [...] Each time I threaten them, there's always a qualification: 'You terrorists, putang ina, I'm going to kill you!' As you see, they end up dead. [...] Some of them are dead. The others, we're still going to kill them. [...] Let's put it this way. I am not about ready to admit any particular killing here. [Laughs.] I can go to prison. What I'm trying to say is that I'm trying hard to make everybody realize, both the civilians and criminals, that if you commit a serious crime, you'll just have to pay for it. Maybe inside the prison or maybe lose your funds or lose your life. [...] No, I should not waive anything there in the Bill of Rights. I think that we should observe it strictly. But if you do not leave room for me to exercise my discretion of human rights or if you do not give me that space, if you box me in one corner, you do not leave me an elbow room to give you, to afford you that right, in the end, you will lose everything [...] maybe including your life" (Rodrigo Duterte cited after: Rody's War 2005).

Actually Duterte is quite popular because of his determined fight against crime. However this fight is not within the limits of the rule of law, but terrorizes criminals and cri- 
criminal-suspects into obedience or flight. Duterte makes abundantly clear that there can be security, but only he himself can provide it. Security is provided according to his personal ideas of justice and adequateness. In his political symbolism, Duterte clearly is above the law. It is him, who indicts, passes judgment and orders the executioners to do their job. It is a personalized fight between those who do not follow the rules and the rightful vigilante whose rules reign supreme. It is boss-rule in pure form.

\section{Conclusion}

The history of the Philippines is a history of boss-rule. Boss-rule in turn is to a significant degree coercion based. The fundamental cognitive bases of continued boss-rule have been patron-client relationships which aim at the creation of some form of vertical solidarity between a patron and his clients, thereby inhibiting the development of horizontal alliances or "class-consciousness" between the clients. Politics in such a system means that "peasants are more or less passively represented [...] in local or regional politics by their particular patrons. Political competition takes on a factional quality inasmuch as the contending units are patron-client networks quite similar to one another in class composition. [...] The overall pattern [...] is that of a disaggregated peasantry attached vertically by bonds of loyalty to agrarian elites who form the active participants in an oligarchic political order" (Scott 1972, 5). This pattern still "comes close to everyday political discourse among politicians and probably still the majority of the people" (Rocamora 1995, XXI). The cognitive patterns underlying boss-rule are not only present in the expressions and practices of the bosses and their henchmen but in the expectations, actions and reactions of the clients alike. Progressive candidates regularly fail to understand the necessities of a clientelist approach, whereas the traditional politicians "understand and are adept at, manipulating the ideological-cultural and quasi religious matrix of local politics" (Rocamora 1995, XXVII). The clientelist approach, however, has never been the benign bond furthering mutual interest. I argue with Sidel, that many visions of patron-client bonding "ignore the persistence of coercive pressures and local power monopolies in electoral politics and social relations" (Sidel 1999, 9). Violence and coercion are and always have been part and parcel of the Philippine variant of clientelism (and most probably of all variants of this type of total, i.e., social, cultural, economic and political order). Repressive violence and coercion are not a sign of the erosion or breakdown of patron-client bonds. As long as the means of violence are to a large extent under the control of the various bosses or patrons - that is, the means of violence are under private control and the state has not yet gained autonomy from the ruling class - the system is intact.

The fact that the state has been effectively put to use for furthering the interests of the ruling elite is not equivalent to saying that the Philippines are a weak state. The Philippine state is actually quite strong in a number of fields dear to the interests of the ruling class and weak in others. And its weaknesses, as argued above, are directly related to the needs of the local elites. Strengthening the state is clearly not in the interest of the local political elites. A strengthened state would imply a weakening of the patron-client relationship and thereby undermine the very foundation of boss-rule.

This has been pointed out by Howard Stein, an early critic of benign theories of patron-client bonding. Stein argues, that patrons will not advocate a strengthening of stateinstitutions, even if these would bring higher productivity, enhanced welfare or security. $\mathrm{He}$ argues that patron-client systems function like protection rackets and mask the coercive side of the "protection" by the "quasi-religion" of the mutually beneficial patron- 
client relationship. Patron-client relationships thrive on the gatekeeper function of the patron. He must make sure, that there are no alternative ways for the client to satisfy his needs except for the patron. The patron and no other mechanism must be the only choice for the client who is in need of protection, security or other immaterial or material goods. It is of fundamental importance that the client can not approach the bureaucracy or the state himself, but has to ask his patron who will then intervene for him. Only in this way can the personalised type of dependency and obligation be created and upheld which is so characteristic of patron-client systems. It is of no importance to the system if clients can change patrons - this may discipline patrons, who are too coercive or oppressive - because the system of personalised and unequal exchange is upheld. Patrons offer protection, however, the "offer of protection [...] is bound up with the perpetuation of the conditions that make protection necessary - and in turn, become part of the threat one needs protection against" (Stein/Hill 1977 cited in: Stein 1984, 32). If patronage is a safety valve for clients in need of certain goods, then at the same time it "serves as a homeostat for a system of inequality. Patronage requires the very gap which it assists the client in bridging. For surely the patron does not help his clients to change the system $[\ldots]$ and thereby abolish the gap" (Stein 1984, 31). Patronage, as Stein points out, needs a paranoid worldview and masks an authoritarian/infantilizing relationship between patron and client, it "requires the hostile universe it mediates" (Stein 1984, 33). Consequently, the patron has to follow two strategies in order to perpetuate his indispensability: he must try to assign members of his family or other trusted henchmen to public office and thereby convert those offices into personal "fiefdoms". Then public goods can be privatized and distributed according to standards of personal loyalty. At the same time, he must persuade his clients, that they can only trust in him and not in the institutions themselves. Therefore he has a direct interest in institutions which do not work properly. If security was safeguarded by the police, if welfare was provided as an equal right by state-institutions to the people, the patron would no longer be necessary.

Necessarily the patrons have no interest in establishing a state monopoly on the means of violence. Even though the costs in terms of development, justice and welfare are high, upholding boss-rule time and again necessitates that the bosses control most of the organized means of violence on a personal basis. Should the police become independent from the local bosses and work as an instrument of independent law enforcement, should the armed forces become independent of personalized political influence and function according to an impersonal logic, should the private armies be abolished, then the coercive foundations of the ruling elite's power would crumble.

\section{Bibliography}

Abinales, P. N./Amoroso, D. J. (2005) State and Society in the Philippines. Pasig City: Anvil.

Abrahams, R. (2008) Some Thoughts on the Comparative Study of Vigilantism. In: Pratten, D./ Sen, A. (Eds.) Global Vigilantes. New York: Columbia University Press, 419442.

Alston, P. (2007) Preliminary note on the visit of the Special Rapporteur on extrajudicial, summary or arbitrary executions, Philip Alston, to the Philippines (12-21 February 2007).www.extrajudicialexecutions.org/reports/A_HRC_4_20_Add_3.pdf. 
Alston, P. (2008) Report of the Special Rapporteur on extrajudicial, summary or arbitrary executions, Philip Alston. (A/HRC/8/3/Add.2, April, 16th). http://daccessods.un.org/access.nsf/Get?Open\&DS=A/HRC/8/3/Add.2\&Lang=E.

Asia Watch (1992) Bad Blood: Militia Abuses In Mindanao, The Philippines. (An Asia Watch Report), New York/Washington, DC: Human Rights Watch.

Balesta, M. A. (pseudonym) (2007) The Blood Politics of Abra. http://www.pcij.org/ireport/2007/abra-politics.html, and: ... abra-politics2.html, ... abra-politics3.html.

Bankoff, G. (1992) Big Fish in Small Ponds: The Exercise of Power in a NineteenthCentury Philippine Municipality. In: Modern Asian Studies, 26(4): 679-700.

Bohannan, C.T.A. (1961) Unconventional Operations. Presentation on a CounterGuerilla Seminar Fort Bragg, June 15th. http://www.icdc.com/ paulwolf/colombia/hukcampaign15june1961V.htm

Council Meeting (1955) The Philippine Experience in Combatting Communist Subversion. Council Meeting Southeast Asia Collective Defense Treaty Bangkok, February 23rd-25th.

http://www.icdc.com/ paulwolf/colombia/phiippineexperience23feb1955.htm.

Espino, I. C. (2004) Counterinsurgency: The Role of the Paramilitaries. Naval Post Graduate School Monterey Calif. Thesis. http://handle.dtic.mil/100.2/ADA429863.

Go, J. (2008) American Empire and the politics of meaning: Elite Political Cultures in the Philippines and Puerto Rico during U.S. Colonialism. Durham/London (Duke University Press).

Greenberg, L. M. (1987) The Hukbalahap Insurrection: A Case Study of a Successful Anti-Insurgency Operation in the Philippines, 1946-1955. Analysis Branch, U.S. Army Center of Military History, Washington, D.C. http://www.history.army.mil/books/coldwar/huk/huk-fm.htm.

Guyot, E. (06.08.1988) Alsa Masa: "Freedom Fighters" or "Death Squads?”. (Letter to Peter Martin, Executive Director. Institute of Current World Affairs, Hanover, USA). http://www.icwa.org/ArticlesMap.asp?r=14.

Hedman, E.-L. (2000) State of Siege: Political Violence and Vigilante Mobilization in the Philippines. In: Campbell, B. B., Brenner A. D. (Eds.) Death Squads in Global Perspective: Murder with Deniability. New York, Houndmill (Basingstoke): Palgrave Macmillan, 125-151.

Hedman, E.-L./ Sidel, J. T. (2000) Philippine Politics and Society in the Twentieth Century: Colonial legacies, post-colonial trajectories. London/New York: Routledge.

Human Rights Watch (1996) The Philippines: Human Rights and Forest Management in the 1990s. April, Report 8(3c). http://hrw.org/reports/1996/Philippi.htm.

Hutchcroft, P. D. (2000) Colonial Masters, National Politicos, and Provincial Lords: Central Authority and Local Autonomy in the American Philippines, 1900-1913. In: The Journal of Asian Studies, 59(2): 277-306.

Hutchroft, P. D. (1991) Oligarchs and Cronies in the Philippine State: The Politics of Patrimonial Plunder. In: World Politics, 43(3): 414-450.

Justiniano, M. T. (1961) Combat Intelligence. Presentation on a Counter-Guerilla Seminar Fort Bragg, June 15th. http://www.icdc.com/ paulwolf/colombia/hukcampaign15june1961IV.htm.

Kerkvliet, B. (1977) The Huk Rebellion: A Study of Peasant Revolt in the Philippines. Berkeley, CA: University of California Press.

Kowalewski, D. (1992). Counterinsurgent Paramilitarism: A Philippine Case Study. In: Journal of Peace Research, 29(1): 71-84. 
Kreuzer, P. (2007) Formen und Dynamiken Politischer Gewalt in den Philippinen. HSFKReport, 8/2007.

Kroef, J. M. van der (1990) The „Rambo Mystique“: Philippine Para-Military and Society. In: Internationales Asienforum, 21(1-2): 5-37.

Kroef, J. M. van der (1986/87) Private Armies and Extrajudicial Violence in the Philippines. In: Asian Affairs, 13(4): 1-21.

Landsdale, E. G. (1961) Introductory Comments on the HUK Campaign. Presentation on a Counter-Guerilla Seminar Fort Bragg, June 15th. http://www.icdc.com/ paulwolf/colombia/hukcampaign15june1961I.htm

Lawyers Committee for Human Rights (1988) Vigilantes in the Philippines: A Threat to Democratic Rule. New York: Lawyers Committee for Human Rights.

Lawyers Committee for Human Rights (1990) Out of Control: Milita Abuse in the Philippines. New York Lawyers Committee for Human Rights.

Leon, T. O./Escobido, G. M. O. (2004) The Banana Export Industry and Agrarian Reform. Davao City (Alternate Forum for Research in Mindanao AFRIM).

Malajacan, M. Q. Jr. (1988) Anti-Communist Vigilantes in the Philippines. Fort Leavenworth, Kansas (Thesis Master of Military Art and Science).

Mediavilla, S. (2007) GMA orders national drive vs private armies. In: The Manila Times, January 25 th. http://manilatimes.net/national/2007/jan/25/yehey/top_stories/20070125top6.html.

Police Regional Office Cordillera (2007) Briefing Handout: House of Representative Committee Hearing, January 29th. http://pcij.org/blog/wpdocs/Task_Force_Abra_Briefing_Report_Jan\%2707.pdf.

Pumecha, A. A. (2007) A Special Report on Peace and Order in the Province of Abra. (Abra Police Provincial Office, Bangued, Abra, February 4th), http://pcij.org/blog/wpdocs/PNP_Abra_Special_Report_Feb\%2707.pdf.

Republican Act No. 6657 (1988) Comprehensive Agrarian Reform Law. www.tanggol.org/environmental_laws/RA6657.html.

Rocamora, J. (1995) Introduction: Classes, Bosses, Goons, and Clans: Re-imagining Philippine Political Culture. In: Lacaba, J. F. (Ed.) Boss: 5 Case Studies of Local Politics in the Philippines. Pasig/Metro Manila: Philippine Center for Investigative Journalism/Institute for Popular Democracy, VII-XXXI.

Rody's war (2005) In: Davao Today, November 6th. http://davaotoday.com/2005/11/06/rody\%E2\%80\%99s-war/.

Rosenbaum, J. H./Sederberg, P. C. (Eds.) (1976) Vigilante Politics. Philadelphia, University of Pennsylvania Press.

Rosenbaum, J. H./Sederberg, P. C. (1974) Vigilantism: An Analysis of Establishment Violence. In: Comparative Politics, 6(4): 541-570.

SAGSD (Security Agencies and Guards Supervision Division) (2008) Philippine Association of Detective and Protective Agency Operators PADPAO. 14 February, http://pnp.gov.ph/down/content/sagsd_forms/padpao.pdf.

Scott, J. C. (1972) The Erosion of Patron-Client Bonds and Social Change in Southeast Asia. In: Journal of Asian Studies, 32(1): 5-37.

Sen, A./Pratten, D. (2008) Global vigilantes: perspectives on justice and violence. In: Pratten, D./Sen, A. (Eds.) Global Vigilantes. New York: Columbia University Press, $1-24$.

Senate Bill No. 2620 (2008) An act defining 'private armies and other armed groups' implementing the constitutional provision for their dismantling, prescribing penalties 
therefore, and for other purposes. September 8th. www.senate.gov.ph/lis/bill_res.aspx?congress $=14 \& q=S B N-2620$.

Sidel, J. T. (1999) Capital, Coercion and Crime: Bossism in the Philippines. Stanford: Stanford University Press.

Simbulan, D. C. (2005) The Modern Principalia: The Historical Evolution of the Philippine Ruling Oligarchy. Diliman, Quezon City: University of the Philippines Press.

Tiglao, R. (1993) Safety Catch. Slow progress in campaign to curb private armies. In: Far Eastern Economic Review, September 16th, p. 26.

Tutay, F. V. (1970a) Portraits of Senator and Congressman as Warlords. In: Philippines Free Press, November 14th, p. 1, 2, 57, 58.

Tutay, F. V. (1971b) "Private Armies" legalized! In: Philippines Free Press, January 23rd, p. 8, 44.

Valeriano, N. D. (1961) Military Operations. Presentation on a Counter-Guerilla Seminar Fort Bragg, June 15th.

http://www.icdc.com/ paulwolf/colombia/hukcampaign15june1961III.htm

Peter Kreuzer, Senior Research Fellow at Peace Research Institute Frankfurt, specializing in comparative political violence; regional expertise: Southeast Asia

E-Mail: kreuzer@hsfk.de 